\title{
Monetary Policy in the Post Keynesian Theoretical Framework
}

\author{
A política monetária na perspectiva pós-keynesiana
}

FÁBIO HENRIQUE BITTES TERRA PHILIP ARESTIS*

RESUMO: O objetivo desta contribuição é desenvolver um modelo pós-keynesiano de política monetária, apresentando seus objetivos, instrumentos e canais de transmissão. A originalidade desta contribuição consiste, seguindo-se as propostas de Keynes (1936, 1945), em se instituir a administração de dívida como um dos instrumentos da política monetária, em conjunto com os tradicionais, taxa de juros e regulação. Ademais, o artigo constrói seu modelo teórico resgatando amplamente os escritos originais de John Maynard Keynes. Um modelo de política monetária erigido desta forma relaciona-se diretamente aos esforços póskeynesianos de oferecer uma forma de condução da política monetária que seja alternativa ao Regime de Metas de Inflação, proposto pelo Novo Consenso Macroeconômico.

PALAVRAS CHAVE: Teoria Keynesiana; Política Monetária; Política Econômica; Taxa de Juros; Administração de Dívida.

ABSTRACT: The purpose of this contribution is to develop a Post Keynesian monetary policy model, presenting its goals, tools, and channels. The original contribution this paper develops, following Keynes's $(1936,1945)$ proposals, is the use of debt management as an instrument of monetary policy, along with the interest rate and regulation. Moreover, this paper draws its monetary policy model by broadly and strongly relying on Keynes's original writings. A monetary policy model erected upon this basis relates itself directly to the Post Keynesian efforts to offer a monetary policy framework substantially different from the Inflation Targeting Regime of the New Macroeconomic Consensus.

KEYWORDS: Keynesian Theory; Monetary Policy; Economic Policy; Interest Rate; Debt Management.

JEL Classification: E12; E5; E42.

\footnotetext{
* Professor of Instituto de Economia da Universidade Federal de Uberlândia, e-mail fhbterra@ie.ufu.br; Director of Research, Cambridge Centre for Economic \& Public Policy, e-mail: pa267@cam.ac.uk. Submitted: 5/April/2016; Approved: 2/May/2016.
} 


\section{INTRODUCTION}

The purpose of this contribution is to develop a Post Keynesian monetary policy model, presenting its goals, tools and transmission channels. Specifically, there are three monetary policy tools in this model: the interest rate, regulation and debt management. In the view of that, the new idea this paper proposes, based on Keynes $(1936,1945)$, is a monetary policy framework in which debt management is one of its instruments, together with those of interest rate and regulation. The debate on debt management was initiated by Tily $(2006,2010)$, who recovered Keynes' ideas on debt management and related them to the liquidity preference theory and monetary policy. However, Tily (op. cit.) did not develop a monetary policy framework in the above mentioned relevant publications; thereby, going further than his original contributions, but referring to them as necessary, this paper develops further Keynes's proposals on debt management, regarding them as a monetary policy tool. Thus, this is the originality of this paper, namely to present Keynes's debt management scheme as an instrument of monetary policy, within a Post Keynesian monetary policy model.

This paper has four additional sections, apart from this short introduction. Second section concisely reviews the concept of monetary economy of production; in effect Keynes's view of capitalist economies. This section is important in that it reminds us of the demand-led nature of monetary economies of production, and to recall Keynes's (1936) liquidity preference theory, which is of central relevance to monetary policy. Third section presents the ultimate and immediate goals of the Post Keynesian monetary policy model that this paper proposes. Fourth section debates the tools available for monetary policy in three sub-sections; the first one portrays the interest rate as a monetary policy tool and its channels of transmission, whereas the second and third sub-sections pursue the same for debt management and regulation, respectively. The final section summarizes and concludes this contribution.

\section{THE CONTEXT OF THE POST KEYNESIAN MONETARY POLICY: MONETARY ECONOMIES OF PRODUCTION}

Keynes $(1933,1936)$ conceptualizes the capitalist system as monetary economies of production, in which investment is the key variable because it determines employment and output levels. Entrepreneurs have money in their hands and seek more of it over time. For they invest money to start a production process, buying capital goods and inputs as well as employing labour and other productive factors. If investment plays such an important role as part of the aggregate demand, it is, then, a very relevant aspect of the economic system.

Thereafter, to explain the relationship between aggregate demand, total income and aggregate supply, Keynes (1936, pp. 25) establishes the principle of effective demand He defines it as "the value of $D$ [demand] at the point of the aggrega- 
te demand function, where it is intersected by the aggregate supply function, will be called the effective demand". In light of this definition, whenever in aggregate the production costs are greater than the sale-proceeds, there is an insufficiency of effective demand and entrepreneurs would not profit. However, what does make the point of effective demand to be in such position that it exactly meets the aggregate supply and sustain the level of employment? Nothing does actually, except for appropriate economic policies.

The reason for an insufficient effective demand lies on the uncertainty concerning the future. Families and entrepreneurs do not and cannot know the future outcomes of their current decisions and so all that they can have from the future is expectations. In this sense, when deciding which asset to buy, business people compare the marginal efficiency of capital with the yield-curve of financial assets. In doing so, first, they decide whether hoarding money or buying liquid short-term financial assets is the best way forward. Then, the comparison is between the return of less liquid long-term financial assets with the marginal efficiency of capital goods. If entrepreneurs have discouraging prospects, they do not engage their wealth in risky activities such as investment, and hoarding becomes the safeguard for their liquidity preference. Consequently, since the economic system is demand-led, whenever pessimistic expectations emerge, the demand of business people for money in relation to capital increases, thereby causing economic growth and employment to change. But why is money demanded is a relevant question.

As is well known, in Keynes's (1936) liquidity preference theory, money is an asset used as a medium of exchange, store of value, and unit of account. More specifically, and in terms of Keynes (op. cit.) position, three reasons explain money demand. There is first the transactions-motive, which expresses the requirement of liquidity as a medium of exchange to settle transactions. Second, there is the precautionary money demand, which is a safeguard against unforeseen events. This liquidity demand transforms money as a store of wealth, so that insufficient effective demand emerges when precautionary money demand increases. Third, the last motive for money demand is the speculative-motive, which is the agents' attempt to profit by holding money to buy financial assets. The speculative motive is of crucial importance to monetary policy because "it is by playing on speculative-motive that monetary management (or, in the absence of management, chance changes in the quantity of money) is brought to bear on the economic system" (Keynes, 1936, pp. 196-7).

The key factor to explain the speculative money demand is expectations, either in general, that is, conventions prevailing in the financial system, or in particular, regarding the difference the agent expects between the actual and future interest rates. The speculative behavior of agents and banks constitutes the supply and demand for liquidity in financial markets; thereby, it establishes the interest rate paid by an asset in particular as well as the economy's interest rate, i.e., the yield-curve of the financial system. Thus, the yield-curve determination depends, on the one hand, on the interaction between the expectations of banks and agents; and on the other hand, it depends on how the central bank accounts for those 
expectations, in its attempt to manage the demand and supply of money, in order to influence expectations, and finally, the own yield-curve. Following Keynes (1936), the importance of the yield-curve and of the monetary policy's attempt to manage it rests on the long end of the yield-curve being the chief variable the entrepreneurs compare with the marginal efficiency of capital when deciding their investment. ${ }^{1}$

Moreover, in monetary economies of production, banks play a relevant role for two main reasons. First, besides the central bank, banks are the other grand players of the financial markets; partly due to their capacity to create money, partly because they are the greatest intermediaries from which the agents can have access to the financial system. ${ }^{2}$ Second, the fact that banks grant finance without the requirement of previous savings explains the endogenous nature of money, which is of fundamental importance to monetary policy. ${ }^{3}$ Hence, banks are not passive firms, responding only to money demand. Like any firm, banks are enterprises seeking profits; thus, a higher effective demand for their services means larger chances for profiting, and this is why the banking system has been developing financial innovations to make its balance sheet management more flexible. Nevertheless, financial innovations also permit banks to deviate from the authorities' regulation as well as from the monetary policy intentions.

To conclude this section, the monetary economy of production is a demand-led economy where investment defines output and employment levels. However, given uncertainty, investment decision-making is based on expectations, which may be, and usually are, too volatile. If expectations are discouraging, the liquidity preference of the business people requires money and other liquid financial assets instead of capital goods, what would push the economic growth down and unemployment up. Yet, market forces, that is the business people's preferences and households' propensity to consume, would not automatically enable job and wealth creation. To avoid this scenario, Keynes $(1924$, pp. 35$)$ required active economic policies, as "even if such a policy were not wholly successful, either in counteracting expectations or in avoiding actual movements, it would be an improvement on the policy of sitting quietly".

\footnotetext{
${ }^{1}$ It is worth remembering that in an open economy, the yield-curve also depends on both the expectations of external investors regarding the future difference between the local and international interest rates and the expected future behavior of the exchange rate

2 The banking system draws into the debate the fourth reason Keynes (1937) gives to elucidate liquidity demand, namely the finance-motive, which refers to the need of entrepreneurs to obtain funds in order to proceed with investment plans.

3 There are several approaches to explain how money is endogenously created. Arestis and Sawyer (2006) offer a broad summary of this issue.
} 


\section{POST KEYNESIAN MONETARY POLICY: ULTIMATE AND IMMEDIATE GOALS}

The goal of Post Keynesian monetary policy must regard what Keynes (1936, pp. 379) affirms as "the outstanding faults of the economic society in which we live [which] are its failure to provide for full employment and its arbitrary and inequitable distribution of wealth and income". In such a context, Keynes (1932, pp. 137) suggests that monetary policy "as a rule, I should expect that its chief problem would be to maintain the level of investment at a high enough rate to ensure the optimum level of employment". Thereby, the straightforward embodiment of Keynes's (op. cit.) concerns in a monetary policy model is setting economic growth as its ultimate goal, which instantaneously brings investment and employment under its surveillance.

Surely, not only should monetary policy pursue economic growth, but also all other economic policies should proceed in accordance with this objective. ${ }^{4}$ However, in order to accomplish this ultimate purpose, each economic policy has its own goals under its direct supervision. In light of that, monetary policy has five immediate goals. First, as Keynes (1932) states, one of these is keeping stable the currency value in terms of wholesale prices - that is, price stability. Inflation affects expectations in general as long as it devalues wealth and shortens the long run.

In explaining inflation, Keynes (1936, pp. 294) argues, "the general price-level depends partly on the rate of remuneration of the factors of production which enters into the marginal cost and partly on the scale of output as a whole, i.e., on the volume of employment". So, prices usually rise while unemployment diminishes, though this means neither that inflation grows proportionally to the unemployment reduction nor that increasing employment is causing inflation, since prices start rising before full employment, due to cost pressures. Furthermore, Sicsú (2003) reviews Minsky (1986), Lavoie (1992) and Davidson (1994), and summarizes seven causes of inflation for the Post Keynesian theory: (1) Profit or monopolist price-making; (2) Wage increases; ${ }^{5}$ (3) Decreasing returns to scale; (4) External factors; (5) Supply-shocks; (6) Tax elevations; and (7) Demand-shocks. Furthermore, we can add two more causes of inflation, Inertia and Expectations. ${ }^{6}$

Keynes (1932, pp. 128) sets the second immediate objective of monetary po-

\footnotetext{
${ }^{4}$ As Arestis (2015) argues, in Post Keynesian economics, there is no room for one economic policy offsetting another; thereby, coordination, seeking the attainment of cumulative positive effects, should be an important principle of Post Keynesian economic policies.

${ }^{5}$ Items (1) and (2) relate to Arestis and Sawyer's (2013) (CILO). In short, the CILO disposes a distributive conflict that triggers a wage-price spiral depending on income-share claims. It presents the intersection of price and wage curves as an inflation barrier, suggesting that monetary policy should keep interest rate as low as sufficient to enhance investment and move the barrier towards full employment. The CILO also permits to conclude that a low interest rate enables a higher inflation barrier because it limits the rentier's power to fight for the income-share.

${ }^{6}$ Inertia is when agents set their prices based on past rates of inflation. Expectations emerge when
} 
licy aiming "at stability of [money] value in terms of an international standard", that is, the exchange rate stability. Given the fact that "any policy on interest rates is inevitable circumscribed by global financial markets" (Arestis and Sawyer, 1998, pp. 187), every time the central bank changes its interest rate, some difference between it and the international interest rate is placed or withdrawn, modifying capital flows and the exchange rate. Unreasonable or harsh exchange rate changes have various consequences on effective demand; they influence expectations, notably those of the firms that either use imported inputs or seek foreign demand. Moreover, firms borrow from foreign financial institutions whereas their returns are in local currency. Hence, if the exchange rate shifts, mismatches between the firm's proceeds and costs materialise, making fragile its financial stance. In addition, devaluations of the exchange rate may pass into domestic prices, pushing inflation up. Lastly, as we will explore in more details below, external capital flows also affect domestic liquidity, and so they impact the yield-curve.

The third immediate goal of monetary policy is "to bring to the forefront a form of monetary and financial policy, which is focused on financial stability" (Arestis and Sawyer, 2009, pp. 511). In short, financial stability is another direct objective of monetary policy. In this sense, Buiter (2008) gives a relevant definition of financial stability: it is the absence of asset price bubbles, illiquidity, and insolvency, whose occurrence threatens the financial markets and the real economy.

In addition, monetary policy transmits its effects through expectations and its counterpart, liquidity preference; so, a good state of expectations is required for the success of central bank policy. This makes the fourth immediate goal of monetary policy, namely the maintenance of stable expectations. If misguided prospects dominate, they result in volatile speculative and precautionary money demand, turning monetary policy ineffective. Given this proposition, Biböw $(2002,2010)$ suggests that transparency and credibility should be the focus of the central bank; likewise, and as Keynes (1936, pp. 203) suggests, "a monetary policy which strikes public opinion as being experimental in character or easily liable to change may fail $[. .$.$] The same policy [...] may prove easily successful if it appeals to public$ opinion as being reasonable and practicable".

The last immediate goal of monetary policy is the supervision and control of liquidity. Monetary policy needs to avoid shortages of liquidity, which would shift the yield-curve; it should also prohibit banks from creating the amount of money that lowers interest rates and, as a consequence, lead to an intense rise in asset prices. Furthermore, central banks should act as lenders of last resort, by means of which they compel an auxiliary effect over expectations too, because both investors and banks have this function as an anchor to their concerns on the financial system's solvency. This lessens their liquidity preference and increases their supply of liquidity to finance the economy.

producers raise prices due exclusively to their expectations, in that the cost of production would increase in their view, which may be baseless. 
There are, therefore, five immediate objectives - the stability of prices, exchange rate, financial system, expectations and liquidity - with which monetary policy directly should deal with to attain its ultimate goal of promoting economic growth towards full employment. Under these circumstances, which are the tools that would enable monetary policy to accomplish all of its multiple goals? As a general rule derived from the broad set of monetary policy objectives, Arestis and Sawyer (2010, pp. 510) suggest, "in terms of the general multiple instruments-multiple objectives framework it may not be possible to uniquely assign each instrument to a specific objective. [...] recognising that coordination in the use of instruments can be advantageous". So, monetary policy instruments are to be used all together, and in a discretionary manner, rather than the 'one-target, one tool' strategy.

\section{POST KEYNESIAN MONETARY POLICY INSTRUMENTS}

Broadly speaking, Keynes's (1930) analysis that monetary policy has the interest rate and regulation as its most important instruments is still the core of the tools for monetary management. Nevertheless, following Keynes (1945), debt management can be regarded as one further instrument for monetary policy. Besides the interest rate and regulation, we also discuss in this section what debt management is and how it channels its effects on effective demand in achieving the monetary policy goals. Thus, the instruments of the Post Keynesian monetary policy rest on three pillars: interest rate, debt management and regulation.

\section{Interest rate}

The central bank interest rate is the price at which it supplies reserves to the banking system. Keynes (1930, pp. 189) deems it as "the governor of the whole system", as long as it is the cornerstone of the financial system yield-curve. Central banks announce their interest rate and then conduct monetary policy in the money market to keep the rate at the announced level. To do so, monetary policy uses either the discount window or open market operations.

The discount window is the supply of reserves the central bank grants to banks that somehow become illiquid. Moreover, monetary policy furnishes its last resort loans through the discount window, upon which it can charge the same interest rate set for open market operations or, otherwise, it can add a punitive surcharge over that rate. Although the discount window portrays the liquidity level intended by monetary policy, open market operations is the most used method to manage the interest rate, in view of the flexibility and speed to achieve results. As Keynes (1930, pp. 225) states, “open-market operations [...] produce a direct effect on the reserves of the member banks and hence on the volume of deposits and of credit generally, by their immediate consequences and apart from their indirect reactions". 
Central banks perform open market operations by buying and selling bonds in the money market, "in other words [...] the aggregate of the central bank's assets is a function of its bank rate, so that by appropriate variations of the latter the whole situation can be controlled" (Keynes, 1930, pp. 224-5). By 'the whole situation' Keynes (op. cit.) means the supply and demand for money, which are utilized to maintain the central bank interest rate stable around its announced level. Thus, open market operations make the central bank rate of interest effective as well as execute the changes in its level.

The interest rate has five transmission channels to effective demand: portfolio, credit, wealth, exchange rate and expectations. Their efficacy depends on three factors: (1) how well central bank manages expectations, mainly by avoiding sudden and huge movements in its interest rate; (2) the agents and banks' reaction to the shifting conditions in the financial markets; (3) the financial system degree of development, given that it is within it that the interest rate effect is channeled on effective demand.

The portfolio channel is one of the transmission channels of the interest rate. Its importance emerges from its direct impact on the investment opportunity cost. Following Keynes's (1936) asset pricing theory, this channel acts by virtue of how agents allocate their portfolios, based on the assets' expected return, cost of carrying, and liquidity. Thereby, at every interest rate change, monetary policy induces agents to reallocate their portfolio, as a reaction to the new conditions. Additionally, as soon as the interest rate starts moving, the yield-curve shifts too, as a result of the general reaction to the changing circumstances throughout the financial system.

The second transmission channel of monetary policy is the four-fold credit channel. It produces effect by means of how financial institutions formulate the interest rate charged on their loans by setting some mark up over the central bank interest rate. Under these circumstances, if the latter rate changes, so does the former, influencing the capital and credit markets, and thereby affecting effective demand via investment and consumption. In the capital market, besides being an opportunity cost, elevated interest rates also signify higher investment costs, depressing the marginal efficiency of capital. Keynes (1930) inspires another interest rate impact in this market. If agents wish to buy securities that finance firms' investment, but they do not own sufficient reserves, 'borrowing to lend' becomes the option. For this strategy to work a stable positive difference between the liabilities' interest rate and the assets' yield is required; thereby, interest rate shifts modify this gap. The other two impacts of the credit channel occur in the credit market; on the one hand, households borrow to consume and a higher credit price reduces this sort of borrowing, pressing effective demand downwards. Likewise, firms borrow working capital, and an increase in the rate of interest modifies their costs, cash flows and, as a result, profits.

The third transmission mechanism of the interest rate is the wealth channel. Keynes (1936, pp. 94) recognizes it as "perhaps the most important influence, operating through changes in the interest rate, on the readiness to spend out of a given 
income". The transmission relies on the impact that interest rate shifts have on the market price of financial assets and then on households' consumption. So, it depends on the degree that households use this changed price to finance their consumption. The more the latter is financed in this way, the larger is the effect of this transmission channel.

The fourth transmission channel operates in open economies. It is the effect of interest rate changes through the exchange rate. Besides the expected variation in the exchange rate, external investors seek the differential between domestic and foreign interest rates when deciding on the contents of their portfolios. Hence, modifications of the local interest rate in relation to the world one, change capital flows and the exchange rate. This movement impacts the cost of inputs, foreign attractiveness of domestic production, and the financial stance of firms with external liabilities. Moreover, capital flows have another relevant effect for which monetary policy needs to account. Every external capital flow changes the money market liquidity, as it requires the conversion of foreign currency into domestic money. Consequently, the financial system yield-curve is affected in view of liquidity changes that emanate from external flows. Whether the economy faces external flows that are either volatile or susceptible to fast reversal in their direction, open market operations need to offset the possible effects of these flows on the money market.

The last interest rate transmission channel is expectations. As Keynes (1936, pp. 197-8) explains,

"it is, however, important to distinguish between the changes in the rate of interest which are due to changes in the supply of money available to satisfy the speculative-motive $[\ldots]$ and those which are primarily due to changes in expectation [...]; Open-market Operations may, indeed, influence the rate of interest through both channels; since they may not only change the volume of money, but may also give rise to changed expectations concerning the future policy of the central bank".

If expectations are as stable as required for conducting monetary policy, different judgments on future interest rates affect the agents' liquidity preference. This diversity of expectations and liquidity preference motivate agents to negotiate debt contracts, guided by their wish to profit by betting on the future interest rates. While agents negotiate in the financial system, there is room for monetary policy to sell and buy public debt with which it makes open market operations. Furthermore, as credibility is a condition for the success of monetary policy, to keep expectations stable the central bank also has to acquaint the agents with the action it takes to bring monetary policy to a successful end.

Bearing all this in mind, it can be said that the expectations channel is a kind of 'channel before other channels' since it is the diversity of opinions about the future interest rates that makes it possible for monetary policy to alter the interest rates so that the other channels transmit their effects on effective demand. Never- 
theless, diversity of individual expectations only happens if the central bank is sufficiently credible, and able to maintain a trustworthy state of expectations. Otherwise, if the central bank fails to build a positive state of expectations concerning how it guides its policy, the relevant state of the financial markets would be disorganised, driving expectations to a high degree of liquidity preference. Under such circumstances open market operations have no space to influence the speculative demand for money and monetary policy would be less effective.

Finally, it is worth highlighting the relation amongst open market operations, interest rate transmission channels and the financial system yield-curve. Open market operations are normally undertaken in the sovereign market, where the central bank and banks transact on public debt. The effects of monetary policy via interest rate changes are thereby transmitted to the other financial markets - namely credit, capital and foreign exchange markets. By means of expectations and portfolio channels, the first transmission emerges while agents are recomposing their assets' portfolio following their altered expectations and liquidity preference. This process terminates in a new financial system yield-curve. Concomitantly, these same expectations and portfolio channels also drive new comparisons between the new yield-curve and the marginal efficiency of capital, driving agents to rearrange their portfolio towards financial or capital assets, what culminates in a new level of investment.

This process goes on through the other channels, eventually influencing effective demand. In the credit market, when the central bank undertakes open market operations, it modifies the cost of consumer credit and, consequently, households' disposition to consume. It also alters the price that firms pay to borrow working capital, affecting their production costs. In the capital market, shifts in interest rates produce two outcomes, the new conditions for agents seeking to borrow money in order to buy securities, and the cost of funding that firms borrow to finance their investment plans. It is also the case that changes in the wealth affect positively households' consumption.

There is also the link between the foreign exchange market and the other financial markets. Depending on the gap between the local and international interest rates and the expected shift in the exchange rate, external capital flows into or out of the economy. For instance, if capital from the rest of the world flows into one country, it first emerges in the foreign exchange market, from which it reaches the money market to be converted into the country's currency. Just after that it goes to the credit and capital markets. In the case when foreign capital leaves the country, the opposite process prevails. Still, external flows pass into the money market and are capable of changing its liquidity level, thus provoking monetary policy action to smooth its impacts on the yield-curve.

\section{Debt management as a monetary policy instrument}

Another idea Keynes (1936, 1945) advances, and Tily $(2006,2010)$ reminds us of, is that the monetary authorities should use public debt with different matu- 
rities in their monetary operations. The reason is that whether open market operations are limited "to the purchase of very short-date securities, the effect may, of course, be mainly confined to the very short-term rate of interest and have but little reaction on the much more important long-term rates of interest" (Keynes, 1936, pp. 197). As discussed above, it is the long-term interest rates that compete with the acquisition of capital goods. When the intention of monetary policy is to boost investment, as it is the case in Post Keynesian economics, the long end of the yield-curve needs to be brought into central bank's wide influence. As Keynes (1945) proposes, debt management can deal with this kind of operation.

Based on Keynes (op. cit.), debt management means economic authorities issuing public debt with different maturities and interest rates, in their attempt to manage the financial system yield-curve throughout. In other words, public debt with various maturities - that is, short-, intermediate- and long-term ${ }^{7}-$ is issued, each type with a diverse interest rate. The idea is to stipulate a combination of public debt's interest rates that guides the financial system yield-curve up to the slope required to stimulate long-term investments. Debt management works as a tool for interest rate administration because public debt is the benchmark for private financial assets. ${ }^{8}$

In terms of its operation, following Keynes (1945), debt management is very much similar to the purchase and sale of bills undertaken in open market operations. However, the crucial difference is that, to reinforce the influence of open market operations on the yield-curve, debt management operates with public debt of medium and long-term maturities, whereas open market operations concentrate on debt of short maturity by means of which it deals with the banks' reserves to keep the short-term interest rate stable. Thus, open market operations are still responsible for influencing, in the money market, the short end of the yield-curve through its control over the central bank interest rate and the banks' reserves. Meanwhile, debt management accounts for the medium- and long-term sections of the yield-curve, by means of the complex of the interest rates of public debt. ${ }^{9}$

In order to undertake proper debt management, a strong and accessible bond market is needed. Moreover, open market operations should continue to be con-

\footnotetext{
${ }^{7}$ Keynes (1945, pp. 399) classifies these maturities as follows: (1) short-term is the time period up to six months; (2) intermediate-term, from five to ten years; (3) long-term, "Savings Bonds (...), with an option to the Treasury to repay after 10 years and with, preferably, no final maturity (or, if necessary, a fixed latest date of repayment 35 years hence)".

${ }^{8}$ This feature emerges from the State's capacity of both collecting resources from society and issuing money. Given that, the State is the most credible agent in the financial markets, and the price it pays for borrowing serves as the reference interest rate for all other debt contracts that agents settle.

${ }^{9}$ Surely, debt management requires coordination of monetary and fiscal policies, which uses public debt too and, in addition, is responsible for both issuing medium- and long-term public debt and arranging the means for its payment. This coordination can be undertaken by a public debt board, established in the central bank - given that it is responsible for managing the interest rate - but containing members of the treasury, in that the latter manages the fiscal policy.
} 
ducted in the money market, given its specific duty of controlling the banks' reserves. Otherwise, debt management is directed to administer the financial system yield-curve, getting it as most prone-to-investment as possible. If these operations were undertaken in the same market, the financial institutions could start an arbitrage process, receiving long-term deposits directed to buy bonds, selling them in the secondary market and using the resources to buy short- or intermediate-term bonds. ${ }^{10}$ The operation in two distinct markets, with different debt terms, conditions of accessing and tax levies, would increase the transaction costs of arbitrage.

The general objective of the central bank in gaining influence throughout the yield-curve is to push the long end of the yield-curve down, administering it around the level compatible with the average scale of the marginal efficiency of capital. As argued above, the yield-curve depends on both the expectations on the future interest rates and the agents' credibility of the monetary policy itself. Thus, as a rule for managing debt over time Keynes (1945, pp. 396) states, "no dogmatic conclusions should be laid down for the future about the rates of interest appropriate to different maturities, which should be fixed from time to time in the light of experience". This discretionary power of the monetary authority is fundamental to furnish debt management "the maximum degree of flexibility and freedom" (op. cit., pp. 397). Still expectations and liquidity preference are always involved in the monetary economies of production; thereby, "continuity of policy and gradualness of changes should be ensured unless in exceptional circumstances and for grave cause" (op. cit., pp. 397).

Debt management has indirect and direct transmission channels to effective demand. Its indirect effects stem from the channels of transmission of the interest rate, which are enhanced by debt management as long as it grants to monetary policy a broader influence over the yield-curve. For instance, in terms of the portfolio channel, debt management enables a less volatile impact of the agent's portfolio composition on the yield-curve, what, in turn, ameliorates the expectations channel. In the presence of debt management, even if the short-term interest rate bears some volatility, the medium- and long ends of the yield-curve are under greater stability because the monetary authority operates on all of its segments. Given that, monetary policy has more room to counteract the trend in the liquidity preference of agents. Furthermore, debt management also influences the exchange rate stability, due to the better control central banks exert upon the difference of the local and the world interest rates.

Debt management is also capable of directly affecting some of the immediate goals of monetary policy, namely price, liquidity, and financial stability. In accordance to the circumstances and given that no harsh and frequent movements are taken on the interest rate, debt management can be used by monetary policy to

\footnotetext{
${ }^{10}$ The Brazilian case, where the bills and bond markets were merged in the high inflation period is very illustrative of this arbitrage problem. For more on this, see Carvalho (2005) and Barbosa (2006).
} 
tackle conjectural problems, helping to stabilize expectations and counteract the economic cycle. For instance, open market operations can bring the short-term interest rate up to face inflation by means of the credit channel; however due to debt management the long-term interest rate may continue favouring investment, improving the overall production capacity and avoiding inflationary supply constrains. Yet, the Federal Reserve Maturity Extension Program, the so-called 'Operation Twist', undertook by the Fed in 2012, illustrates the case in which debt management was undertaken to stimulate economic activity. The USA central bank used the proceeds of short-term bills to buy long-term bonds, furnishing liquidity to this segment of the financial market and bringing the long end of the yield-curve down. The Fed's intention was to foster investment, counter-acting the effects of the international financial crisis of 2007/2008. Furthermore, debt management spreads public debt through the financial system, widening the capacity of the central bank to control liquidity in all the financial markets. This improves monetary policy in its handling of liquidity and helps in its efforts to guaranteeing financial stability. Still, regarding financial stability, a widespread use of public debt makes the financial system more robust, due to the opportunity of the public debt being offered as better quality collateral in loans. Last but not least, if for some reason the agents' expectations turn their liquidity preference volatile making them run from private debt, the presence of accessible public debt of various maturities and yields creates a range of financial assets options to ease the agents' flight-to-liquidity. Hence, the overall liquidity preference can be kept more stable over time because agents have, on their need for liquid assets, the chance to acquire public debt. When the flight-to-liquidity is overcome, the monetary authority can repay bonds of different maturities, even by issuing money, rendering liquidity and stability to the financial system.

Figure 1 presents the case of how debt management operates as a monetary policy tool. In this Figure, the vertical axis shows the two main rates of return taken into consideration by entrepreneur financial assets and the marginal efficiency of capital. . The horizontal axis shows time and risk of the overall assets. The upward slope in both the financial system yield-curve and public debt yield-curve, accounts for the higher gain sought by investors as uncertainty increases and investments become riskier over time. In turn, point I in Figure 1 reports the exactly higher level of the long-term interest rate below which investments are not undertaken; beneath this point, it is better to buy financial assets rather than capital goods. In this context, if monetary policy is acting to stimulate investment towards full employment, it should make all the required effort to keep the long end of the yield-curve at least equivalent to the marginal efficiency of capital. 


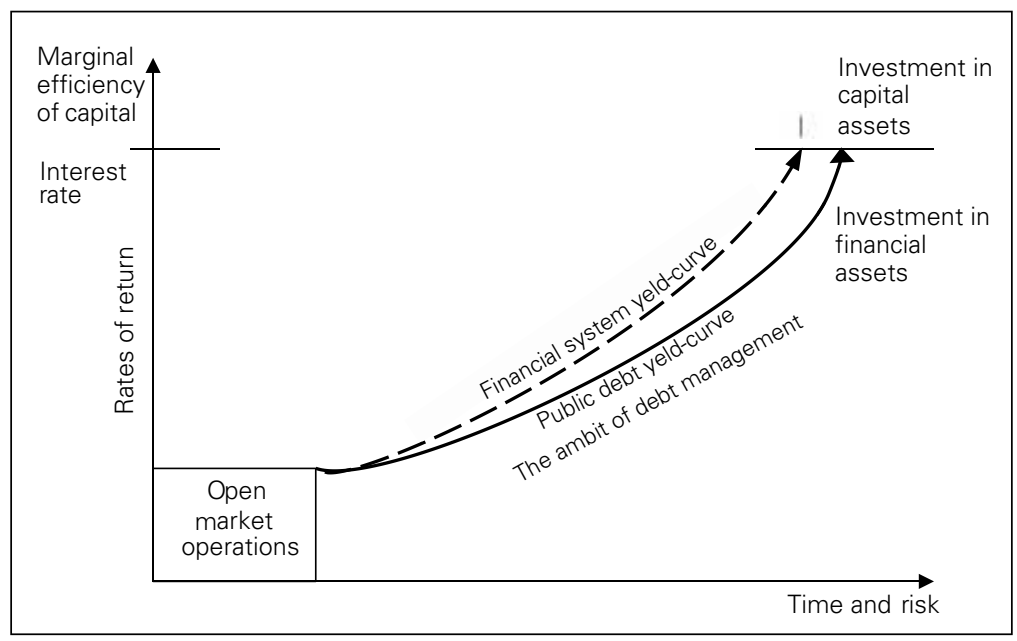

Source: Authors' own construction.

Without debt management, Figure 1 would not have the public debt yield-curve guiding the financial system yield-curve. In that case, the monetary policy's stimulus to investment would be undertaken only by open market operations; thereby, monetary policy would concentrate itself solely on the short-end of the financial system yield-curve, having little effect on its long-term segment, the relevant one for the investment decision, as point I in Figure 1 shows. In fact, this is the way in which monetary policy has been performed as central banks undertake open market operations to keep stable the short-term interest rate they set. Still, even in this case the intention of the monetary authority is to influence the yield-curve throughout, although acting only at its short-term. In this case, agents and financial institutions would largely act freely to define the long-term interest rate, so that central banks have less power to set a long-term interest rate that does not perform a high opportunity cost to investment.

However, following Figure 1's logic, debt management can exert an influence on the whole yield-curve. Debt management implies that monetary policy operates with various maturities of public debt; for it tries to create the benchmark interest rate to the private debt and because of that, it can influence the yield-curve on its entire extension, making it easier to set a long-term interest rate that enables investment levels to be undertaken - as per point I in Figure 1. For instance, if the long-term interest rate is increasing due to expectations of inflation or exchange rate devaluation, central banks can concomitantly increase the short-term interest rate of the bills they use in open-market operations and keep stable the interest rate of their long-term bonds. While doing that, monetary authorities act both at the short- and the long-ends of the yield-curve. So, they do not attempt to establish some long-term interest rate by only working with short-term maturity debt. Figure 1 presents this process by means of debt management influencing the 
financial system yield-curve throughout up to point I. This explains why Keynes argues that, when central banks undertake debt management, they "can make both the short and long-term whatever they like, or rather they feel to be right having regard to possibilities of under or over-employment and other social reasons" (1945, pp. 392).

Finally, in the case where debt management is not undertaken, the only way to influence the long-term segment of the yield-curve would be fiscal policy. By means of the bonds the Treasury issues to finance budget disequilibrium, fiscal policy could try to exert some influence on the long-term interest rate. Nevertheless, the aim of the Post Keynesian fiscal policy, as Arestis et al. (2015) show, is not related to control the financial system yield-curve, but deals with automatically stabilizing the economic cycle and fully exploring the investment multiplier through a long-term programme of public investments. That is why we argue that debt management should be a monetary policy tool, as it is the task of the monetary administration to manage all the complexities of the interest rates of the financial system. Therefore, debt management as a monetary policy instrument requires close coordination between fiscal and monetary policies, so that the closer this coordination is, the better is the use of the public debt by these two policies; and, also, the greater is the influence of the economic policy over the finance system yield-curve.

\subsection{Regulation}

Regulation is, of course, the other monetary policy tool. It is a legal enactment in the form of acts and laws that economic authorities undertake in order to regulate how agents, i.e. all domestic and external financial institutions, non-financial firms, and households, behave in the financial system. Regulating the financial system means that each financial product needs to be addressed by some legal act, which rules how the transaction should be settled. Otherwise, if deregulation prevails, a range of financial products would not be under surveillance, putting the financial stability at risk.

Hence, it does not matter how many forms the financial transactions and products assume, regulation should address all of them. For example, regulation is intended to avoid the operation of the so-called shadow banking system, as well as it sets either the amount of compulsory reserves commercial banks provide to the central bank or the conditions a bank must fulfill to receive a last resort loan. It also defines the minimum time period an external financial investment should remain in the economy, and the division line between commercial and investment banks, among others. As these examples show, the measures of regulation should spread themselves through the whole financial system so as to promote its stability. ${ }^{11}$ In this sense, regulation establishes what should be undertaken within the

\footnotetext{
${ }^{11}$ See Grabel (2006), Palley (2006), Arestis and Sawyer (2011), Arestis and Karakitsos (2013), and Goodhart et al. (2013), for further examples of financial regulation.
} 
borders of the financial system; restraining and opening trails that local and foreign agents pursue. ${ }^{12}$ Although regulation must be uninterruptedly updated, it should not change abruptly; otherwise, it is difficult for agents to fix their portfolio strategies, culminating in liquidity preference changes and unstable speculative money demand.

The transmission channel of regulation is both direct and indirect. In view of this and given that regulation assumes a wide sort of forms, to illustrate how it works as a monetary management tool, we will pay attention to two kinds of regulation, namely the requirement of compulsory reserves (Keynes, 1930) and macroprudential measures (Goudard and Terra, 2015). On the one hand, the direct effect of regulation is its power to control agents' financial behavior. In fact, this evidently is one of the ways by which monetary policy reaches its goal of keeping the financial system stable. For instance, reserve requirements create a direct monetary policy effect as they form a buffer of resources that central banks promptly use when the economic system needs liquidity. Macroprudential measures are also a tool to forge financial stability. Goudard and Terra (2015) define them as enactments for building up financial stability by placing qualitative and quantitative limits to loans in general. So, they restrain the range of strategies available to financial institutions, avoiding their incursion into endogenous pro-cyclical, cross-sectional and cross-border risks (in this latter case, regulation means capital controls). ${ }^{1313}$ Aware of the endogenous nature of the pro-cyclical risk, the macroprudential regulation triggers more restrictive rules in the upward phase of the cycle, when "the popular estimation of the magnitude of both these risks, both borrower's risk and lender's risk, is apt to become unusually and imprudently low" (Keynes, 1936, pp. 145).

On the other hand, the indirect effect of regulation is its function to aid the management of the interest rate. Once again, macroprudential regulation exemplifies this, because it reduces the central bank interest rate sensitivity with respect to shifts in both the financial asset prices and foreign capital flows. The former is explained by the fact that when macroprudential measures are in place, the central bank interest rate does not need to avoid asset price bubbles solely; macroprudential regulation is also responsible on this score. In turn, the diminution of the central bank interest rate elasticity in relation to the exchange rate movements derives itself from the control of external flows imposed by macroprudential measures, especially so if the regulation focuses on very short-term speculative capital flows. Macroprudential capital controls reduce the exchange rate oscillation and, as a

\footnotetext{
${ }^{12}$ Regulation for financial stability may be an independent policy in relation to monetary policy. However, a successful monetary policy crucially depends on the behavior and soundness of the relevant financial system. Then, in our point of view, the central bank should be in charge of the financial stability policy.

${ }^{13}$ If transactions are between domestic financial institutions, a cross-sectional risk is set. Whether foreign institutions are involved, there is a cross-border risk. All these risks are endogenous in Minsky's (1986) sense, i.e. they emerge from the normal function of the economy (Goudard and Terra, 2015).
} 
consequence, prevent interest rate volatility, providing autonomy for monetary policy in relation to the external sector.

Figure 2 summarizes the Post Keynesian monetary policy proposed in this paper. The logic of the Figure goes from its left hand side to the right side and the arrows symbolize the relationship between the variables. This logic can be described as follows. Post Keynesian monetary policy operates with three tools, (1) the interest rate, which is set through the discount window and, chiefly, through open market operations; (2) debt management, which impacts on the interest rate management; likewise it immediately acts on the stability of price, financial system and liquidity; and (3) regulation, which has indirect effects, in that it helps the interest rate management; and also direct effects as it controls the agents' behavior in the financial system, contributing to its stability. In turn, the interest rate has five transmission channels: the portfolio channel; the credit channel; the wealth effect; the exchange rate channel; and the expectations channel. Every time the central bank changes the interest rate it impacts one or more of these transmission channels; thus, they reach the immediate goals of monetary policy, namely, the stability of prices, exchange rate, liquidity, financial system and expectations. All of them affect the immediate goals of monetary policy and thereby effective demand. Because they impact effective demand, they are essential for reaching the ultimate objective of the Post Keynesian monetary policy, that is, the full-employment economic growth. Figure 2 - A summary of the Post Keynesian monetary policy

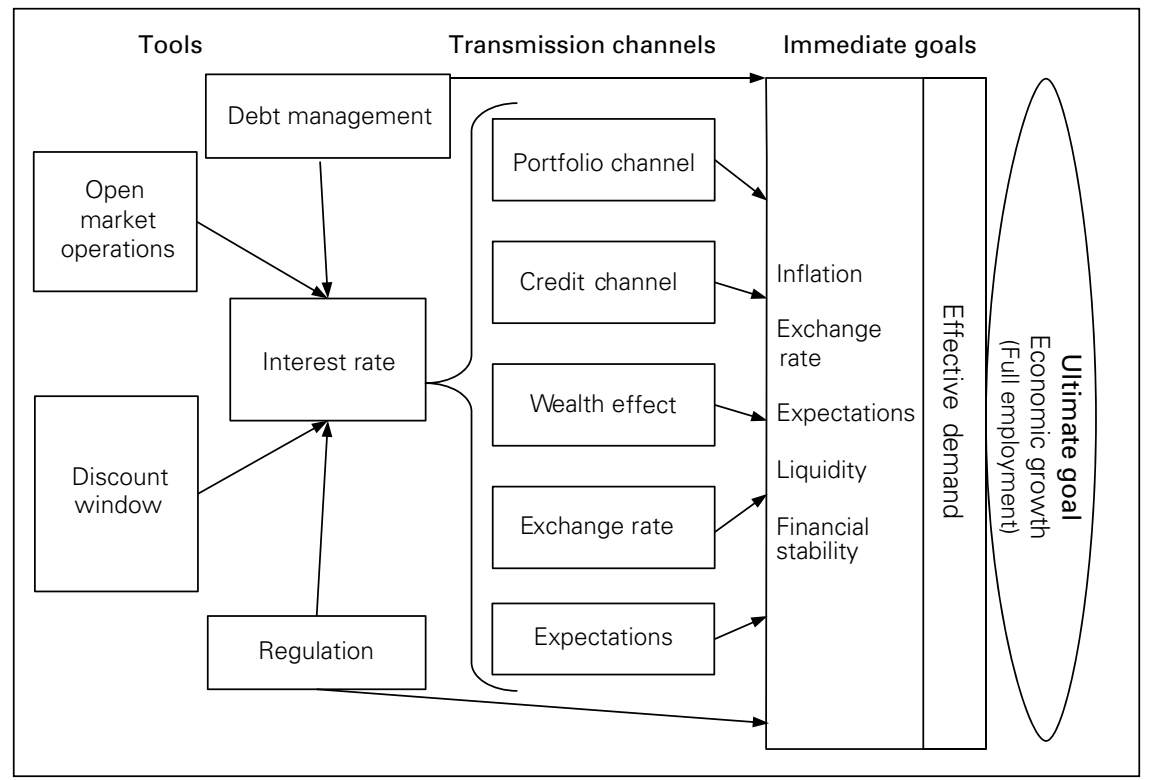

Source: Authors' own construction. 
As Figure 2 also illustrates, because of the various and complex relations between tools, transmission channels and the broad set of immediate goals that monetary policy keeps under its surveillance, there is the need for the central banks to coordinate the use of their tools. When undertaken in a coordinated manner, these tools provide a better channel in terms of their various effects. For instance, this is the case of using debt management to keep stable the long-term interest rate along with open market operations. Another example is the use of regulation over short-term speculative foreign capital, which provides the interest rate greater autonomy to deal with domestic issues, making it less sensitive to international capital flows.

Last but not least, all the relations presented in Figure 2 show that the implementation of monetary policy is a complex task. Yet, this must not result in the necessity of rules restraining the monetary policy operation to one single policy objective, as the Inflation Targeting Regime requires. On the contrary, Post Keynesian monetary policy requires pragmatism and discretion, obviously focused on public welfare, so that the central bank acquires power to react to the various exogenous (e.g. natural disasters) and endogenous (e.g. procyclical financial fragility or exchange rate devaluations) shocks that modify the variables it should keep stable.

\section{SUMMARY AND CONCLUSIONS}

The Post Keynesian monetary policy aims to promote full-employment economic growth. To do so, monetary policy has to achieve five immediate goals: stability of prices, exchange rate, financial system, liquidity and expectations. To accomplish them, monetary policy can use its two classical tools, the interest rate and regulation, and it should also undertake debt management as one further instrument at its disposal. Debt management is an instrument able to improve the administration of the interest rate, given that it is aimed at influencing the yield-curve throughout, making it less difficult for monetary policy to set a prone-to-investment yield-curve. Notwithstanding this influence, debt management is also capable of affecting some of the immediate goals of monetary policy, turning it into a more active policy.

Moreover, Post Keynesian monetary policy requires credibility, transparency, commitment of policy makers to public welfare, pragmatism, and discretionary power to adjust the appropriate instruments in accordance with the on-going circumstances. This is even more important given the complexity of the monetary policy operation and its broad range of goals vis-à-vis its limited number of tools. In this sense, monetary policy must build good expectations about the future so that it persuades agents, mainly the business community, to expand the level of effective demand until the one needed to reach full employment.

Finally, in the monetary economies of production, coordinated economic policies enable the economic system through establishing the best available institutional environment for expectations and, as a consequence, for investment. Mo- 
netary policy is one of these policies. It is a powerful instrument for various reasons: it is able to stimulate investment by means of shaping a yield-curve that does not create an opportunity cost to capital goods - which is the main role for debt management. Furthermore, it is also capable of boosting cheaper consumer credit as well as fostering 'borrow to lend' operations that agents undertake when they buy securities in the capital market. In light of all these arguments, monetary policy should not be restrained to dealing solely with inflation as the Inflation Targeting Regime demands. By contrast, it should be implemented in the way the Post Keynesian monetary policy clearly suggests, as this has been highlighted in this contribution.

\section{REFERENCES}

Arestis, P., Terra, F. H. B. and Ferrari-Filho, F. (2015). The Post Keynesian macroeconomic policy regime. Proceedings of the $19^{\text {th }}$ Annual Conference of the Research Network Macroeconomics and Macroeconomic policies, "The Spectre of Stagnation? Europe in the World”. Berlim, October.

Arestis, P. (2015). "Coordination of fiscal with monetary and financial policies can better cure unemployment”, Review of Keynesian Economics, 3(1): 233-47.

Arestis, P. and Karakitsos, E. (2013). Financial Stability and the Aftermath of the Great Recession, Basingstoke: Palgrave Macmillan.

Arestis, P. and Sawyer, M. (1998). "Keynesian economic policies for the new milleniun” The Economic Journal, 108(446): 181-95.

Arestis, P. and Sawyer, M. (eds.). (2006). A Handbook of Alternative Monetary Economics, Aldershot: Edward Elgar.

Arestis, P. and Sawyer, M. (2010). "What monetary policy after the crisis?" Review of Political Economy, 22(4): 499-515.

Arestis, P. and Sawyer, M. (2011). "A new paradigm for macroeconomic policy". International Journal of Public Policy, 7(1/2/3): 22-39.

Arestis, P. and Sawyer, M. (2013). "Moving from inflation targeting to prices and incomes policy". Panoeconomicus, 1(1): 1-17.

Biböw, J. (2002). "Keynes on central banking and the structure of monetary policy". History of Political Economy, 34(4): 749-87.

Biböw, J. (2010). "A Post Keynesian perspective on the rise of Central Bank Independence: a dubious success story in monetary economics". The Levy Economics Institute of Bard College Working Paper, n. 625.

Buiter, W. (2008). "Central banks and financial crises”. Discussion paper of Financial Markets Group, London School of Economics and Political Science, n. 619.

Davidson, P. (1994). Post Keynesian Macroeconomic Theory, Aldershot: Edward Elgar.

Barbosa, F. H. (2006). "The contagion effect of public debt on monetary policy: the Brazilian experience", Revista de Economia Política, 26(2): 231-38.

Carvalho, F. J. C. (2005). "Uma contribuição ao debate em torno da eficácia da política monetária e algumas implicações para o caso do Brasil”, Revista de Economia Política, 25(4): 323-36.

Goodhart, C.; Hartmann, P.; Llewellyn, D.; Rojas-Suarez, L., Weisbrod, S., (2013), Financial Regulation: Why, How and Where Now? New York: Routledge.

Goudard, G. and Terra, F. B. (2015). "Uma leitura pós-keynesiana das medidas macroprudenciais”. Revista Análise Econômica, 33(63): 171-90.

Grabel, I., A. (2006). "Post-Keynesian analysis of financial crisis in the developing world and directions for reform". In: Arestis, P. and Sawyer, M. (eds.), A Handbook of Alternative Monetary Economics, Aldershot: Edward Elgar, 403-19. 
Keynes, J. M. (1937). “Alternative theories of the interest rate”, Economic Journal, 47, (186): 241-52.

Keynes, J. M. (1924, [1971A]), “Tract on monetary reform”. The Collected Writings of John Maynard Keynes, IV, Londres: Royal Economic Society.

Keynes, J. M. (1930, [1971B]), "A Treatise on Money - the applied theory of money". The Collected Writings of John Maynard Keynes, VI, Londres: Royal Economic Society.

Keynes, J. M. (1933, [1973A]), The General Theory and After: a supplement. The Collected Writings of John Maynard Keynes, XXIX, Londres: Royal Economic Society.

Keynes, J. M. (1936 [1973B]), The General Theory of Employment, Interest and Money. The Collected Writings of John Maynard Keynes, VII, Londres: Royal Economic Society.

Keynes, J. M. (1945 [1980]), Activities 1940-1946: Shaping the Post-War world - employment and commodities. The Collected Writings of John Maynard Keynes, XXVII, Londres: Macmillan.

Keynes, J. M. (1932, [1982]), The monetary policy of the Labour Party. The Collected Writings of John Maynard Keynes, XXI, London: Royal Economic Society.

Lavoie, M. (1992), Foundations of Post-Keynesian Economic Analysis, Aldershot: Edward Elgar.

Minsky, H. (1986), Stabilizing an Unstable Economy, New Heaven: Twentieth Century Fund Report.

Palley, T. (2006). "Monetary policy in an endogenous money economy". In: Arestis, P. and Sawyer, M. (eds.), A Handbook of Alternative Monetary Economics, Aldershot: Edward Elgar, 242-57.

Sicsú, J. (2003). “Políticas não monetárias de controle da inflação: uma proposta keynesiana”, Revista Análise Econômica, 21(39): 115-36.

Tily, G. (2006). “Keynes's theory of liquidity preference and his debt management and monetary polices”. Cambridge Journal of Economics, 30: 657-70.

Tily, G. (2010). Keynes Betrayed - The General Theory, the Rate of Interest and 'Keynesian' economics, Basingstoke: Palgrave MacMillan. 